\title{
The importance of diastolic dysfunction in the development of weaning-induced pulmonary oedema
}

\author{
Filippo Sanfilippo* (D), Cristina Santonocito, Gaetano Burgio and Antonio Arcadipane \\ See related research by Liu et al. http://ccforum.biomedcentral.com/articles/10.1186/s13054-016-1533-9
}

The group of Prof. Monnet et al. [1] elegantly described the characteristics of patients failing spontaneous breathing trials (SBTs; $\mathrm{n}=128 / 283,45 \%$ ), confirming that a large proportion of weaning failures (59\%) are associated with weaning-induced pulmonary oedema (WiPO). Three factors were independently associated with WiPO during SBT: chronic obstructive pulmonary disease, obesity and "structural cardiopathy".

However, we believe this study also deserves comment for the contribution of LV diastolic dysfunction (LVDD) in cases of WiPO. Despite patients with WiPO having similar LV ejection fraction to those without (61 versus $57 \%, p=0.76)$, they had a higher $\mathrm{E} / \mathrm{E}^{\prime}$ ratio (10.5 versus $8.8, p<0.01)$, a parameter strongly associated with LVDD [2]. Furthermore, among patients with cardiac output $(\mathrm{CO})$ monitoring in place during the SBT $(\mathrm{n}=$ $85 / 283$ ), those developing WiPO showed a significant increase in global end-diastolic volume $(\sim 200 \mathrm{ml},+22 \%$ from baseline), while this parameter remained unchanged when WiPO did not occur. Interestingly, the vast majority of patients experiencing WiPO $(n=28 / 30)$ had preload-independence after a passive leg rising (PLR) test and, on the contrary, the PLR test showed preload-dependence in all the patients that did not experience WiPO $(n=55 / 55)$. The authors also reported that when preload-independence persisted despite fluid removal, most of the patients again showed WiPO on the following SBT, while a change to a preloaddependence condition was associated with a high rate of successful weaning.

Taken together, such findings emphasize the importance of LVDD as a contributor to WiPO. The higher venous return during the shift from positive to negative

\footnotetext{
* Correspondence: fgsanfilippo@ismett.edu

Department of Anesthesia and Intensive Care, IRCCS-ISMETT (Istituto

Mediterraneo per i Trapianti e Terapie ad alta specializzazione), Via Tricomi 5, 90127 Palermo, Italy
}

(c) The Author(s). 2017 Open Access This article is distributed under the terms of the Creative Commons Attribution 4.0 International License (http://creativecommons.org/licenses/by/4.0/), which permits unrestricted use, distribution, and reproduction in any medium, provided you give appropriate credit to the original author(s) and the source, provide a link to the Creative Commons license, and indicate if changes were made. The Creative Commons Public Domain Dedication waiver (http://creativecommons.org/publicdomain/zero/1.0/) applies to the data made available in this article, unless otherwise stated. pressure ventilation determines unfavourable LV loading conditions, which may be poorly tolerated in the context of LVDD.

The importance of LVDD is not surprising since it has been associated with weaning failure $[3,4]$ and also with mortality in sepsis [5]. Of note, the authors report a higher incidence of septic-related cardiomyopathy in patients with WiPO (17 versus $2 \%, p=0.01$ ) [1].

We ask the authors to share their opinion on this aspect and to provide the E' values comparing patients with or without WiPO, since the recently published guidelines have emphasized also the role of E' when assessing LVDD [2].

On a separate note, another interesting finding that may deserve further comment is that patients with $\mathrm{CO}$ monitoring had a trend towards lower SBT failure $(\mathrm{n}=$ 45/85) compared to those with no CO monitoring ( $\mathrm{n}=$ 83/198; $p=0.09$, not reported). Was the CO monitoring intentionally used to keep the patient in a "safely dry" condition?

\begin{abstract}
Abbreviations
CO: Cardiac output; LV: Left ventricular; LVDD: Left ventricular diastolic dysfunction; SBT: Spontaneous breathing trial; WiPO: Weaning-induced pulmonary oedema
\end{abstract}

\section{Acknowledgements \\ None. \\ Funding \\ Not applicable.}

Availability of data and materials

Not applicable.

\begin{abstract}
Authors' contributions
All the authors read and discussed the critical issues of the manuscript by Liu et al. FS wrote the draft of the letter, FS and CS reviewed the evidence on diastolic dysfunction and weaning, GB and AA edited the draft. FS submitted the letter. All authors read and approved the final manuscript.
\end{abstract}

Competing interests

The authors declare that they have no competing interests. 


\section{Consent for publication}

Not applicable.

\section{Ethics approval and consent to participate}

Not applicable.

Published online: 11 February 2017

\section{References}

1. Liu J, Shen F, Teboul JL, Anguel N, Beurton A, Bezaz N, Richard C, Monnet X. Cardiac dysfunction induced by weaning from mechanical ventilation: incidence, risk factors, and effects of fluid removal. Crit Care. 2016;20(1):369.

2. Nagueh SF, Smiseth OA, Appleton CP, Byrd BF, 3rd, Dokainish H, Edvardsen T, Flachskampf FA, Gillebert TC, Klein AL, Lancellotti P, et al.

Recommendations for the evaluation of left ventricular diastolic function by echocardiography: an update from the American Society of

Echocardiography and the European Association of Cardiovascular Imaging. Eur Heart J Cardiovasc Imaging. 2016;17(12):1321-1360.

3. Papanikolaou J, Makris D, Saranteas T, Karakitsos D, Zintzaras E, Karabinis A Kostopanagiotou G, Zakynthinos E. New insights into weaning from mechanical ventilation: left ventricular diastolic dysfunction is a key player. Intensive Care Med. 2011:37(12):1976-85.

4. Caille V, Amiel JB, Charron C, Belliard G, Vieillard-Baron A, Vignon P. Echocardiography: a help in the weaning process. Crit Care. 2010;14(3):R120.

5. Sanfilippo F, Corredor C, Fletcher N, Landesberg G, Benedetto U, Foex P, Cecconi M. Diastolic dysfunction and mortality in septic patients: a systematic review and meta-analysis. Intensive Care Med. 2015;41(6):1004-13

Submit your next manuscript to BioMed Central and we will help you at every step:

- We accept pre-submission inquiries

- Our selector tool helps you to find the most relevant journal

- We provide round the clock customer support

- Convenient online submission

- Thorough peer review

- Inclusion in PubMed and all major indexing services

- Maximum visibility for your research

Submit your manuscript at www.biomedcentral.com/submit
Biomed Central 